\title{
SOUND AND MEANING OF MEGALITHIC TRADITIONAL VILLAGE AS A TOURISTIC CONSUMPTION
}

\author{
Francisca Titing Koerniawaty ${ }^{1}$, I Wayan Ardika ${ }^{2}$ \\ International Institute of Tourism and Business, Indonesia ${ }^{1}$. \\ Udayana University, Indonesia ${ }^{2}$ \\ koe.titing@gmail.com¹, ardikawayan52@gmail.com²
}

\begin{abstract}
This study aims were to criticize and analyse the patterns of cultural heritage of megalithic traditional village-Bena. The sound and meaning were to reflect the domestic and international tourists towards the cultural heritage of megalithic traditional village-Bena as a touristic consumption. Bena is the oldest and well-preserved of a megalithic traditional village located in Ngada Regency, East Nusa Tenggara Province. This qualitative study with ethnographic approach led to depth analysis on tourists' perception towards the megalithic traditional village of Bena as a touristic consumption. The minority of tourists' complaint constructs or damages, doesn't it?
\end{abstract}

Keywords : Megalithic traditional village, touristic consumption.

\section{INTRODUCTION}

Bena is a traditional village of megalithic located in Tiworiwu Village, Jerebu'u District, Ngada Regency, in the middle of Flores Island, East Nusa Tenggara Province. This cultural heritage is still well preserved and the oldest among other traditional villages as representation of Indonesia's cultural assets that are still active and has its existence nowadays (living heritage). The meaning of cultural products will not be damaged, since tourists are accustomed to accepting them, even products can be stated to be authentic if their characteristics are considered authentic, whereas they have acquired commodification transformation. Authenticity needed to satisfy tourists, in turn, depends on the depth of tourist experience desired by each tourist. Based on the indication above, generally, this study has a beneficial insight to analyze tourism studies related to the implications of destination management on tourist perceptions and satisfaction. The tourists' perception towards the megalithic traditional village of Bena as a touristic consumption was analyzed with the commodification and authenticity concept at cultural heritage. The attraction asset of megalithic traditional village of Bena which was analyzed involving the traditional wooden houses with thatched roof which 
functions as a living room for clan's gathering as well as a homestay for tourists. The sacredness of traditional ceremony to respect and give a gratitude for ancestors and the ritual to officiate traditional wooden house by involving all villagers was also a part of commodification. This touristic attraction is still well preserved as a representation of Indonesia's cultural assets that are still active as a living heritage.

The existence of traditional villages as heirs, conservationists, as well as perpetrators of local wisdom, has the potential to maintain cultural identity and build awareness of cultural diversity in Indonesia. Beside it is being a national identity, cultural asset can also carry the economic benefits because, since it is one of the attractions of cultural tourism. Cultural tourism is an experience for urban tourists to experience new things and enjoy the sensation of being in a real and authentic place (Pedersen, 2002). The excessive use of culture as touristic consumption can result in cultural erosion which may reduce the aesthetics of products and traditions, furthermore it may damage nature as well. This superficial assumption lacked common sense, since the meaning of cultural products will not be damaged, since the tourists are accustomed to accepting them, even products can be authentic, as long as their characteristics are considered authentic, while they have been exposed by commodification transformation (Urry, 1995; Cohen, 1988; Burns dan Holden, 1995). Cohen (1998) supported that the authenticity needed to satisfy tourists, in turn, depends on the depth of tourist experience desired by each tourist, since qualified tourists don't really need the depth.

\section{Literature Review}

The previous studies which used as references is the study by Yang (2012:59-81) entitled 'Tourists' perceptions of ethnic tourism in Lugu Lake, Yunnan, China.' Secondly, by Day et al (2015:53-67) entitled 'Perceptions of Authenticity At A Heritage Destination: An Examination Of Visitor Perceptions of Authenticity At South Luogu Alley, Beijing.' The theory of commodification is used to analyze the patterns of cultural heritage of traditional megalithic village-Bena. The authenticity theory isused to analyze the tourist's perception.

\subsection{Commodification}

Commodification is termed as a touristic or commercialization which can be interpreted as a process associated with the symptoms of capitalism to expand the market, increase the maximum profit by making products or services that are liked by consumers (Picard, 2006). It is the process of various things and activities that are evaluated for the exchange of values in trade contexts such as goods or services. The development of exchanges such as the exchange of goods or activities is expressed as market prices (Cohen, 1988). The economic value generated through the commodification process is generally considered positive if it is in accordance with traditional, artistic aspects with modern production features as long as it is maintained at an adequate level and can contribute to the development of a community identity that helps to preserve the culture in order to survive (Proschel, 2012). The patterns of commodification involves production, distribution and consumption processes (Fairclough, 1995; Pitana, 2006; Meekaew and Srisontisuk, 2014). This reproduction of local cultural as tourist consumption is an effort to improve the quality of life of indigenous people (Ardika, 2007). 


\subsection{Authenticity}

The theory of authenticity was introduced by MacCannell (1973) and Wang (1999) to define the originality, reality, and reliability of museums. Authenticity as a social interpretation observed, not as a real and objective phenomenon that can be seen empirically (Bruner 1989, 1994; Cohen, 1988; Handler and Linnekin 1984; Lanfant 1989; Spooner 1986; Taylor 2001; Wood 1993). This authenticity can be negotiated (Cohen, 1988), depending on the context (Salamone 1997), ideology (Silver 1993), dreams, images, or expectations of tourist destinations (Bruner 1991; Silver 1993). The ideology and typology of authenticity as a limitation of the theory of authenticity. The first ideology is modernism or realism. Boorstin (1961) and MacCannell (1973) suggested that object authenticity can be tested or assessed through certain standards. In tourism, artworks, artifacts, cuisine, or ritual products are usually described as authentic or inauthentic, depending on the traditions carried out by indigenous. Secondly, the ideology of constructivism contradicts modernist ideas. Authenticity as a social interpretation can be observed, not as a real and objective phenomenon that can be seen empirically (Bruner 1989, 1994; Cohen, 1988; Handler and Linnekin 1984; Lanfant 1989; Spooner 1986; Taylor 2001; Wood 1993). Thirdly, postmodernist ideology does not concern objects that are inauthentic, it is not fundamental to state between real or false, authentic or copy, reality or symbol, even Eco (1986) tried to erase the boundary between copy and authentic.

According to Cohen (1995), tourists could accept the lack of authentic, origin, and reality. Postmodern tourists do not care about the authenticity and origin of the attractions as long as they can be enjoyed. If a product transformed by the commodification process maintains characteristics that satisfy tourists, it will remain authentic. A philosophy by Heidegger claims that the term authentic can be implemented on objects that mean real, authentic, untouched, or pure. Tourists who think authentic then what is in this world is considered authentic, human power determines the essence or form of authenticity (Heidegger, 1977a, b). Souvenir production for the purpose of benefiting local people separates authentic meanings (Halewood and Hannam 2001).

The typology of authenticity as a theoretical limitation is objective, constructive, and existential authenticity (Cohen, 1988; Pearce \& Moscardo 1986; Waitt, 2000; Wang, 1999). Objective authenticity is used to test whether a work of art is real. Thus, it can measure the value and price of goods (Trilling, 1972). Objective authenticity claimed that the culture of the local community can be staged which is called the authenticity of pseudoevents (Boorstin, 1961), but this theory has the disadvantage of not being able to explain the whole phenomenon of tourism. To address this weakness, (Wang, 1999) proposed constructive authority that considers five criteria for authenticity, namely: the absence of absolute criteria for assessing authenticity, traditions built to fulfill the development needs at a certain time, interpretation of events, activities, and physical arrangements can influence perceptions of authenticity, expectations tourists are associated with authenticity, over time the authenticity of an object can change. Tourists do not pursue authenticity, most of them enjoy and accept events that are staged and reprogrammed (Bruner, 1991; Chhabra, Healy, \& Sills, 2003; Cohen, 1988; Moscardo \& Pearce, 1999; Yang \& Wall, 2009). Thus, it can be said that 
reproduction tends to be accepted if it is indeed authentic (Bruner, 1991).

Existential authenticity is different from objective and constructive. Kim and Jamal (2007), Wang (1999) define existential authenticity as authentic and independent experiences, since the tourists can get out of the routine through escaping from the pressures of everyday life not because they feel the authenticity of tourist destinations.

All the insight of the authenticity revealed that the commodification of Bena cultural heritage was perceived as an authentic experience by the domestic and international tourist.

\section{METHODOLOGY}

This is a qualitative descriptive study using an ethnography approach, conducted in 2018 that analysed in depth, in detail and holistically the patterns of cultural heritage of the Bena traditional megalithic village and the perception of domestic and international tourists towards the cultural heritage of the Bena megalithic traditional village as a touristic consumption. Primary data was obtained through passive participatory observation and in-depth interviews to the selected informants who were understood the research problem involving indigenous people, domestic and international tourists by using purposive and snowball sampling techniques. Secondary data was obtained through documentation studies on pattern of cultural heritage of the megalithic traditional village of Bena as touristic and the perception of international and domestic tourist towards cultural heritage of the megalithic traditional village of Bena as a touristic consumption.

\section{RESULTS AND DISCUSSION}

The Patterns of Cultural Heritage of Traditional Megalithic Village of Bena as a Touristic

The patterns of commodification involved production, distribution and consumption processes (Fairclough, 1995; Pitana, 2006; Meekaew dan Srisontisuk, 2012). This reproduction of local culture is an effort to improve the quality of life of indigenous people (Ardika, 2003; 2007; 2015). In accordance with this statement, it could be stated thar the first main pattern of cultural heritage product of Bena as a touristic consumption, namely ' $N u a$ ' involving the uniqueness of traditional wooden houses, namely Sao Saka Pu'u and Sao Saka Lobo. Another uniqueness of the traditional house which becomes the main attraction of cultural tourism is the spatial design consisting of three rooms namely Tedha Wena, Tedha Oné and Oné. Tedha Wena is a semi-open veranda which its function to display several traditional woven clothes, receiving guests, relaxing, and eating or doing other social activities. The next room is Tedha Oné as a living room which is functioned as a men's bedroom and dining room. This room is merely can be entered by family members and the closest relatives. The core room of the traditional house, namely Oné as a private room and is considered as a holy or sacred place, since it is functioned as the place where traditional ceremonies are held. Based on its function, this room has a double meaning that is sacred as a place of traditional 
ceremonies and profane as a place for the women activities to cook, take a rest and eat with the family.

The second pattern of cultural product as a touristic consumption is a traditional indigenous ceremony of $\mathrm{Ka} \mathrm{sa}^{\prime} \mathrm{O}$ and Reba,' including several attractions during the ceremony such as a traditional dance of $J a^{\prime} i$ with euphonic music instrument, a unique traditional woven costume of $\mathrm{Ikad}$, ceremonial attributes such as colorful plastic bead necklaces, and women and men's traditional bags of Bere. The uniqueness of local language used by the shaman in leading the ritual through prayers has a sacredness, as well as traditional food $R a$ 'a rete, steamed casava and Moke drinks typical of Bena are always consumed during the ceremony.

Since the Traditional Village of Bena was established as a cultural tourism destination in 1990, the traditional houses, aside from being a place of residences, are also functioned as homestays. The total number of traditional houses used as lodging is forty-one (41) inhabited by nine different tribes. The homeowners are women, since they adhere to the matrilineal kinship system that means every house is named according to the names of the heiresses.

\section{The Tourists' Perception Towards Megalithic Traditional Village of Bena}

The existential authenticity as authentic and independent experiences since the tourists can get out of the routine through escaping from the pressures of everyday life rather than their perceived to the authenticity of tourist destinations (Kim and Jamal, 2007), Wang (1999). The tourists do not need the authenticity and origin of the attractions, since it can satisfy tourists, it will remain authentic. Fourthly, Heidegger's philosophy claims that the term authentic can be implemented on objects that mean real, authentic, untouched, or pure. Tourists who think authentic then what is in this world is considered authentic, human power determines the essence or form of authenticity (Heidegger, 1977a, b). Souvenir production for the purpose of benefiting local people separates authentic meanings (Halewood and Hannam 2001). There are five criteria for authenticity that proposed by (Wang, 1999). Those are the absence of absolute criteria for assessing authenticity, traditions built to fulfil the development needs at a certain time, interpretation of events, activities, and physical arrangements can influence perceptions of authenticity, expectations tourists are associated with authenticity, over time the authenticity of an object can change. Tourists do not pursue authenticity, most of them enjoy and accept events that are staged and reprogrammed (Bruner, 1991; Chhabra, Healy, \& Sills, 2003; Cohen, 1988; Moscardo \& Pearce, 1999; Yang \& Wall, 2009). It means the reproduction tends to be accepted if it is indeed authentic (Bruner, 1991).

In accordance with the authenticity ideology and typology, it could be stated that the megalithic traditional village of Bena was perceived as an authentic cultural heritage destination with the criteria of genuine, unique, antique, and traditional. The accessibility to the destination area was stated in good condition with very large parking area outside the destination area. The entrance ticket is considered reasonable. In spite of a little interaction is given due to the communication barrier in English, the indigenous people are considered pure in welcoming tourists. There were no complaints against indigenous children who asked for money or candy 
when photographed or when tourists passed through the traditional wooden houses as well as a genuine player of traditional flute who entertained without asking any fees to both international and domestic tourists.

The majority of tourists stated that the architecture of traditional wooden houses is unique, traditional, authentic, and typically village, whereas the tourists are lack of understand to the history of the traditional megalithic village. The rest rooms as supporting facilities needed to be maintained regularly. The officers at TIC should be more friendly and should always provide much information to tourists about the stories and history of the traditional megalithic village of Bena.

The ceremonial of a new house blessing $K a s^{\prime} o$ and Reba are perceived as a unique, sacred, pure and typically village ceremonial. The tourists perceived the authentic experience by involving the ceremony. The uniqueness and sacredness of rituals could be perceived from its local languages and traditional music instrument. The traditional dancing, wearing local traditional costume, and consuming the traditional local drink and food were perceived as an authentic experience. The minority of women tourists stated that slaughtering of sacrificial animals was not uncommon, since the way to slaughter the sacrificial animals by swinging a long knife into the pig's forehead. The host stated wisely that this ritual has been carried down and well preserved from generation to generation by ancestors for sacredness purpose than for pleasure.

The traditional food Ra'a Rete, steamed casava and Moke drinks typical of Bena perceived as an authentic experience, since both international and domestic tourists involved with the indigenous people to consume it altogether during the ceremonial. The minority of international tourists stated that serving the traditional food with the bare hands were not hygienic, it should be served with traditional utensils to keep hygienic. The indigenous children have a positive perception from both international and domestic tourists since they didn't ask any contribution when photographed as well as a flute player genuinely in entertaining the tourists.

The perceptions towards Bena woven cloth of Ikat and traditional bags was stated as an authentic experience since the tourists experienced to wave the local traditional fabric at each veranda of the traditional wooden houses and could see several women waved the local fabric traditionally. The tourist perceived that bargaining the souvenir price with the local woman was a unique interaction. The woman in every veranda of the traditional wooden houses didn't push any tourists to buy the local souvenirs. The tourists prefer to buying organic colour of the local woven than chemical colour, since the organic seemed antique and unique. The local traditional woven motive was typically traditional village. The traditional bag of Bere made of Lotar wore as an attribute of the ceremonial costume was perceived more unique than plastic.

\section{CONCLUSION}

The patterns of commodification include the process of production, distribution and consumption of the cultural heritage of Bena traditional village, namely $\mathrm{Nua}$ in the form of constructing and or renovating the traditional wooden houses, namely Sao Saka Pu'u and Sao Saka Lobo as a place to live and gathering of all clans, as well as being used as homestays which are distributed to attract 
visitor's interest through brochures, local government official social media and other stakeholders' social media and word of mouth. The traditional ceremony of $K a a^{\prime} O$ is a new house blessing ceremonial which was merely attended by members of the clan. However, it could be consumed as a tourist attraction. Reba is a sacred ceremony as a thanksgiving to the ancestors, which is scheduled on the web of the East Nusa Tenggara and Ngada, Lonely Planet and TripAdvisor tourism agencies to make it easier for tourists to get information on the uniqueness of the ceremony. The production of traditional woven cloth of Ikat and traditional bags of Bere were to fulfill an attribute of traditional ceremonial costume. It has re-produced, distributed, and consumed to tourists to improve the quality of life of indigenous people.

Most of both international and domestic tourists stated that the overall cultural product of the traditional megalithic village of Bena was distributed and consumed as an authentic experience, since the tourists have never perceived it in other cultural heritage destination and also in their countries. The criteria of the authenticity experience were indicated with pure, unique, antique, natural, traditional, and typical rural destination.

The minority complaint from both international and domestic tourist concerning public facilities, indigenous' hospitality, providing sufficient information about the history of the traditional megalithic village, traditional food hygienic should be considered as a positive recommendation to preserve the sustainability of local heritage culture a touristic consumption.

\section{ACKNOWLEDGEMENTS}

The research was made to fulfill the author's doctoral degree study requirements. The authors would like to thank to the traditional megalithic village of Bena family and the management of The Bali Institute of Tourism and Business International as a sponsor to this research.

\section{REFERENCES}

Ardika, I Wayan. (2003). Pariwisata Budaya Berkelanjutan. Refleksi dan Harapan Di Tengah Perkembangan Global. Denpasar: Program Studi Magister (S2) Kajian Pariwisata Universitas Udayana.

(2007). Pusaka Budaya dan Pariwisata. Denpasar: Pustaka Larasan.

(2015). Warisan Budaya Perspektif Masa Kini. Denpasar: Program Studi Magister (S2) Kajian Pariwisata Universitas Udayana.Haykin, S. (1994).

Boorstin, D. (1961). The Image: A Guide to Pseudo-Events in America. New York: Harper and Row.

Burns, P. Holden, A. (1995). Tourism: a New Perspective. New Jersey: Prentice Hall.

Bruner, E. M. (1989) Tourism, Creativity, and Authenticity. Studies in Symbolic Interaction 10:109-14.

(1991). Transformation of Self in Tourism, Annals of Tourism Research 18:238250.

(1994). Abraham Lincoln as Authentic Reproduction: A Critique of Postmodernism. American Anthropologist 96:397-415. 
Chhabra, D., Healy, R., Sills, E., (2003). Staged Authenticity and Heritage Tourism. Annals of Tourism Research. Vol. 30 (3): pp. 702-719.

Cohen, E. (1988). Authenticity and Commoditization in Tourism. Annals of Tourism Research 15:371-86.

(1993). The Heterogenization of a Tourist Art. Annals of Tourism Research . 20:138163.

(1995). Contemporary Tourism Trends and Challenges: Sustainable Authenticity or Contrived Post-modernity? In Change in Tourism: People, Places, Processes, Richard Butler, and Douglas Pearce, eds., pp. 12-29. London: Routledge.

Day, J., Shi, X., Cai, L., Adler, H. (2015). Perceptions of Authenticity at a Heritage Destination: An Examination of Visitor Perceptions of Authenticity at South Luogu Alley, Beijing. Tourism Analysis, Vol. 20: pp. 53-67.

Eco, U. (1986). Travels in Hyperreality. London: Picador.

Fairclough, (1995). Discourse and Social Change. Cambridge: Polity Press.

(1995). Situations and Stand points in Archaeology and Heritage. Leaf Cost Press Inc. Washington DC.

Halewood, C. Hannam, K. (2001) Viking Heritage Tourism: Authenticity and Commodification. Annals of Tourism Research, Vol. 28: pp. 565-580.

Handler, R., dan J. Linnekin. (1984). Tradition, Genuine or Spurious. Journal of American Folklore 97:273-290.

Heidegger, (1977a). The Age of the World Picture. In the Question Concerning Technology and Other Essays, W. Lovitt, ed., pp. 115-154. New York: Harper and Row.

(1977b). The Question Concerning Technology. In The Question Concerning Technology and Other Essays, W. Lovitt, ed., pp. 3-35. New York: Harper and Row.

Kim, H., \& Jamal, T. 2007. Touristic quest for existential authenticity. Annals of Tourism Research, Vol. 34 (1), 181-201.

Lanfant, M. (1989) International Tourism Resists the Crisis. In Leisure and Life style, A. Olszewska and K. Roberts, eds., pp. 178_193. London: Sage.

MacCannell, D. (1973). Staged Authenticity: Arrangements of Social Space in Tourist Settings. American Journal of Sociology, Vol. 79 (3):pp. 589-603.

Meekaew, N. Srisontisuk, S. (2012). Chiangkhan: Cultural Commodification for Tourism and Its impact On Local community. Proceedings-Management, Agroindustry and Tourism Industry-004, 4th International Conference on Humanities and Social Sciences April 12th.

Pedersen, A. (2002). Managing tourism at world heritage sites. A practical manual for World Heritage site managers. ICOMOS.

Pearce, P.L., Moscardo, G.M. (1986). The Concept of Authenticity in Tourist Experiences. The Australian and New Zealand Journal of Sociology, 22:121-132.

(1999). Understanding ethnic tourists. Annals of Tourism Research, Vol. 26 (2), 416-434.

Picard, M. (). Bali: Pariwisata Budaya dan Budaya Pariwisata. (Couteau, J, Wisatsana, W, Translator) Kepustakaan Populer Gramedia: Jakarta.

Pitana, I.G. (2006). Bali Bangkit Kembali: Industri Budaya Dalam Pariwisata Bali: 
Reproduksi, Presentasi, Konsumsi, dan Konservasi Kebudayaan. Kerjasama Departemen Kebudayaan dan Pariwisata Republik Indonesia dan Universitas Udayana.

Pröschel, N. (2012). Commodification and Culture. How can culture be economically used without selling it out. Thesis. Tourism and Hospitality Management Vienna University.

Salamone, F. A. (1997). Authenticity in Tourism: The San Angel Inns. Annals of Tourism Research. 24:305-321.

Silver, I. (1993). Marketing Authenticity in Third World Countries. Annals of Tourism Research, 20:302-318.

Spooner, B. (1986). Weavers and Dealers: The Authenticity of an Oriental Carpet. In: The Social Life of Thing.

Taylor, J. (2001). Authenticity and Sincerity in Tourism. Annals of Tourism Research, 28:17-26.

Trilling, L. (1972). Sincerity and Authenticity. London: Oxford University Pres.

Urry, J. (1990). The Tourist Gaze. London: Sage. In: Ali-Knight, J. M. (2011). The Role of Niche Tourism Products in Destination Development. Edinburgh: Napier University.

Wang, N., (1999). Rethinking Authenticity in Tourism Experience. Annals of Tourism Research, vol. 26 (2): pp. 349-370.

Waitt, G. (2000) Consuming Heritage-Perceived Historical Authenticity. Annals of Tourism Research, vol. 27 (4), 835-862.

Wood, R. E. (1993). Tourism, Culture and the Sociology of Development. In: M. Hitchcock,V. King and Parnwell, M. Tourism in Southeast Asia, , eds., pp. 48-70. London: Routledge.

Yang, L., \& Wall, G. (2009). Authenticity in Ethnic Tourism: Domestic Tourists Perspectives. Current Issues in Tourism, vol. 12 (3): pp. 235-254.

Yang, L. (2012). Tourists' perceptions of ethnic tourism in Lugu Lake, Yunnan, China. Journal of Heritage Tourism, vol. 7, 2012 - Issue 1: pp. 59-81. 